\title{
Anatomical Behavior of the Celiacomesenteric Artery of Pirarucu Arapaima gigas Cuvier, 1817 (Osteoglossiforme, Arapaimidae)
}

\author{
Comportamiento Anatómico de la Arteria Celiacomesentérica en \\ Pirarucu Arapaima gigas Cuvier, 1817 (Osteoglosiforme, Arapaimidae)
}

\begin{abstract}
André Luiz Quagliatto Santos; Fernando Moraes Machado Brito; Andréa Cristina Scarpa Bosso; Lucélia Gonçalves Vieira; Luiz Martins da Silva Junior; Arthur Paulino Sanzo Kaminishi; Juliana Macedo Magnino Silva; José Guilherme Souza Pinto; Mariela Silva Moura \& Marcelo de Alcântara Rosa
\end{abstract}

SANTOS, A. L. Q.; BRITO, F. M. M.; BOSSO, A. C. S.; VIEIRA, L. G.; SILVA JR., L. M.; KAMINISHI, A. P. S.; SILVA, J. M. M.; PINTO, J. G.S.; MOURA, M.S. \& ROSA, M. A. Anatomical behavior of the celiamesenteric artery of pirarucu Arapaima gigas Cuvier, 1817 (Osteoglossiforme, Arapaimidae). Int. J. Morphol., 25(4):683-687, 2007.

SUMMARY: The pirarucu, Arapaimidae family fish, is one of the most important and emblematic species of Amazon. To investigate their circulatory system anatomics features were used 10 specimens with $74 \mathrm{~cm}$ medium total length, from river Araguaia lakes, São Miguel do Araguaia, Goias, Brazil. The fishes had their celomatic cavity open with dorsal aorta artery identified and cannulation where was injected synthetic latex. Fixation of those specimens was by injection of $10 \%$ formalin. In that specie, the coeliac-mesenteric artery is the only one arterial vessel responsible to digestive tract flow and always ramified from $2^{\text {nd }}, 3^{\text {rd }}$ and $4^{\text {th }}$ left efferent branchial arteries. The stomach is flowing by coeliac artery and a gastric branch of the cecal ventral artery; intestine receives coeliac-mesenteric artery branchs and cranial and caudal mesenterics arteries branchs; the dorsal and ventral cecum are supplied by cecal dorsal and ventral arteries respectively.

KEY WORDS: Arapaima gigas; Arteries; Stomach; Intestine; Osteoglossiformes.

\section{INTRODUCTION}

Fishes are the most successful vertebrates in terms of biomass and number of species, but descriptions of the physiology of their vascular system have been largely and often inappropriately based on the cardiovascular system of mammals (Farrell, 1993).

Teleost fishes make up the most diverse group among the vertebrates, encompassing an estimated 20,000 living species divided into approximately 38 orders (Richter et al., 2000), among them that of the Osteoglossiforms, which comprise two families, the Osteoglossidae and the Pantodontidae. Today, Arapaima gigas is classified as Arapaimidae, which is endemic to the Amazon basin and an obligatory air-breather (Val ; Almeida-Val, 1995).

Arapaima gigas is undoubtedly one of the most important and emblematic species of the Amazonian ichthyofauna, due not only to its size but also to the historical role it has played in fishing and in the region's socio-economic context (Guimarães, 2005).

The pirarucu offers the rural producer another option in the choice of species for intensive and extensive fish farming, thus ensuring the preservation of this species, which is under threat of extinction (Silva et al., 1995).

The study of the circulatory system of fishes has attracted the attention of many researchers, including Pollak (1960), who, in his study of Perca fluviatis, stated that the caudal segmental arteries have corresponding arteries in the trunk in the form of mesenteric arteries, and that the celiacomesenteric artery always originates from the $3^{\text {rd }}$ and $4^{\text {th }}$ right efferent branchial arteries. According to Bond (1996) and Cailliet et al. (1986), the arteries that supply the viscera and the musculature are branches of the aorta and of the caudal artery. 
SANTOS, A. L. Q.; BRITO, F. M. M.; BOSSO, A. C. S.; VIEIRA, L. G.; SILVA JR., L. M.; KAMINISHI, A. P. S.; SILVA, J. M. M.; PINTO, J. G. S.; MOURA, M. S. \& ROSA, M. A. Anatomical behavior of the celiamesenteric artery of pirarucu Arapaima gigas Cuvier, 1817 (Osteoglossiforme, Arapaimidae). Int. J. Morphol., 25(4):683-687, 2007.

Several studies have highlighted the importance of knowledge about the blood vascularization of fishes, among them Davison et al. (1997), who documented the control of the peripheral vascularization of Antarctic fishes, which is widely unknown.

In their study of the gills and vascular anatomy of Latmeria, Vogel et al. (1998) focused on the secondary circulation. Evans (2001), in turn, investigated the response of the aorta artery to a variety of signaling agents.

Matsushita (2001) conducted an anatomical study of the cardiovascular system of Hoplias malabaricus, Hoplerythrinus unitaeniatus (Erythrinidae), and Prochilodus lineatus (Prochilodontidae) and found that one of the most conspicuous morphological differences was the bifurcation of the visceral dorsal aorta, which was present only in the Erythrinidae species studied.

Hill et al. (2002) studied the effects of three anesthetics on the cardiovascular system of Oncorhynchus tshawytscha, while Lo et al. (2003) evaluated the effect of cannulation of the aorta artery in immunological studies on Epinephelus malabaricus.

Donald et al. (2004), who investigated the nature of the mechanisms of vasodilatation of the dorsal aorta artery of Rhinobatus typus, found neural synthesis of nitric oxide in fibers of the perivascular nerves in the aorta and in other arteries and veins.

The purpose of this investigation was to describe the origin, ramification and distribution of the celiacomesenteric artery of piracuru.

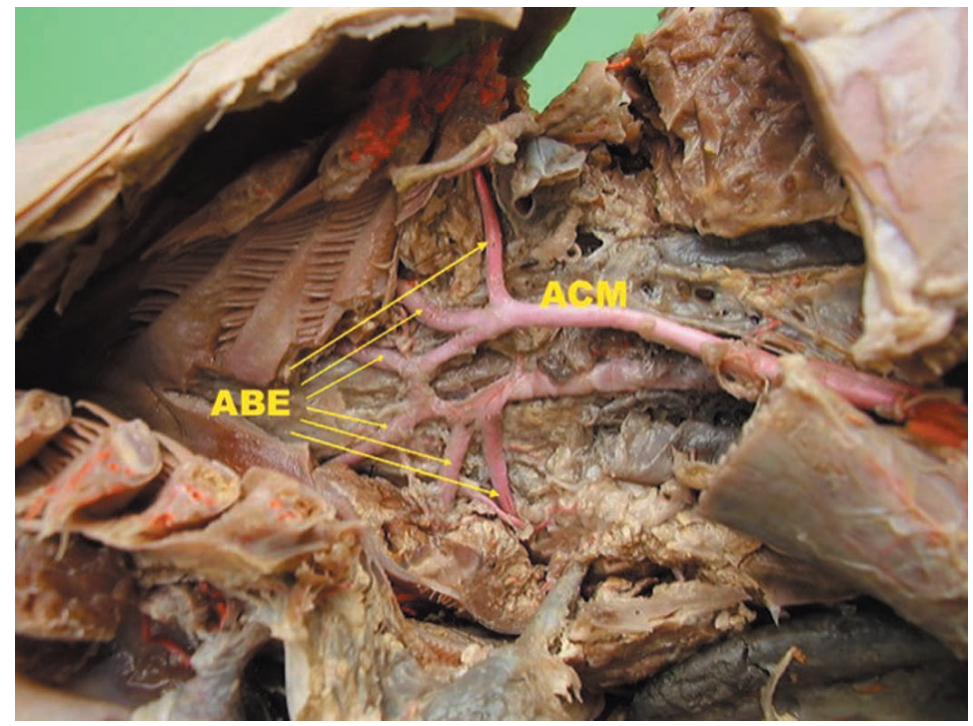

Fig. 1. Cranial view of the head. ABE - efferent branchial arteries, ACM celiacomesenteric artery.

\section{MATERIAL AND METHOD}

Ten specimens of pirarucu (Arapaima gigas), with a total average length of $74 \mathrm{~cm}$, captured in lakes in the Araguaia River in the region of São Miguel do Araguaia, state of Goiás (under permit no. 167/2000 - DIFAS/IBAMA), were used in this experiment.

After their biometry and identification, the animals were frozen and taken to the Wild Animal Research Laboratory (LAPAS) of the Federal University of Uberlândia Faculty of Veterinary Medicine. There, the specimens were defrozen under running water and the celomatic cavity was opened by a longitudinal incision along the ventral median line and two other transversal incisions in the lateral walls of the cavity.

The dorsal aorta artery was then intubated with a 2$\mathrm{mm}$ diameter, 50-mm long polyethylene cannula through which physiological solution was introduced to wash the system. A neoprene latex 450 dye solution (Du Pont do Brasil S.A.-Indústrias Químicas) was then injected.

The material thus prepared was fixed by injecting it with an aqueous solution of $10 \%$ formaldehyde and stored. The specimens were dissected using conventional surgical material. Upon conclusion of the dissection, photographic records were made of the material.

\section{RESULTS}

The celiacomesenteric artery of piracuru results from the joining of the $2^{\text {nd }}, 3^{\text {rd }}$ and $4^{\text {th }}$ left efferent branchial arteries (Fig. 1) and represents the only visceral artery destined for the digestive tube.

Close to the transition from the stomach to the intestine, the celiacomesenteric artery bifurcates into the celiac artery and the cranial mesenteric artery, first supplying the hepatic artery and the dorsal cecal artery. A branch emerges from the hepatic artery to the proximal portion of the intestine.

After a short median trajectory, the celiac artery emits the ventral cecal artery, after which it forks into the right and left gastric arteries. These last two vessels are destined, respectively, to the right and left walls of the stomach, from which 
SANTOS, A. L. Q.; BRITO, F. M. M.; BOSSO, A. C. S.; VIEIRA, L. G.; SILVA JR., L. M.; KAMINISHI, A. P. S.; SILVA, J. M. M.; PINTO, J. G. S.; MOURA, M. S. \& ROSA, M. A. Anatomical behavior of the celiamesenteric artery of pirarucu Arapaima gigas Cuvier, 1817 (Osteoglossiforme, Arapaimidae). Int. J. Morphol., 25(4):683-687, 2007.

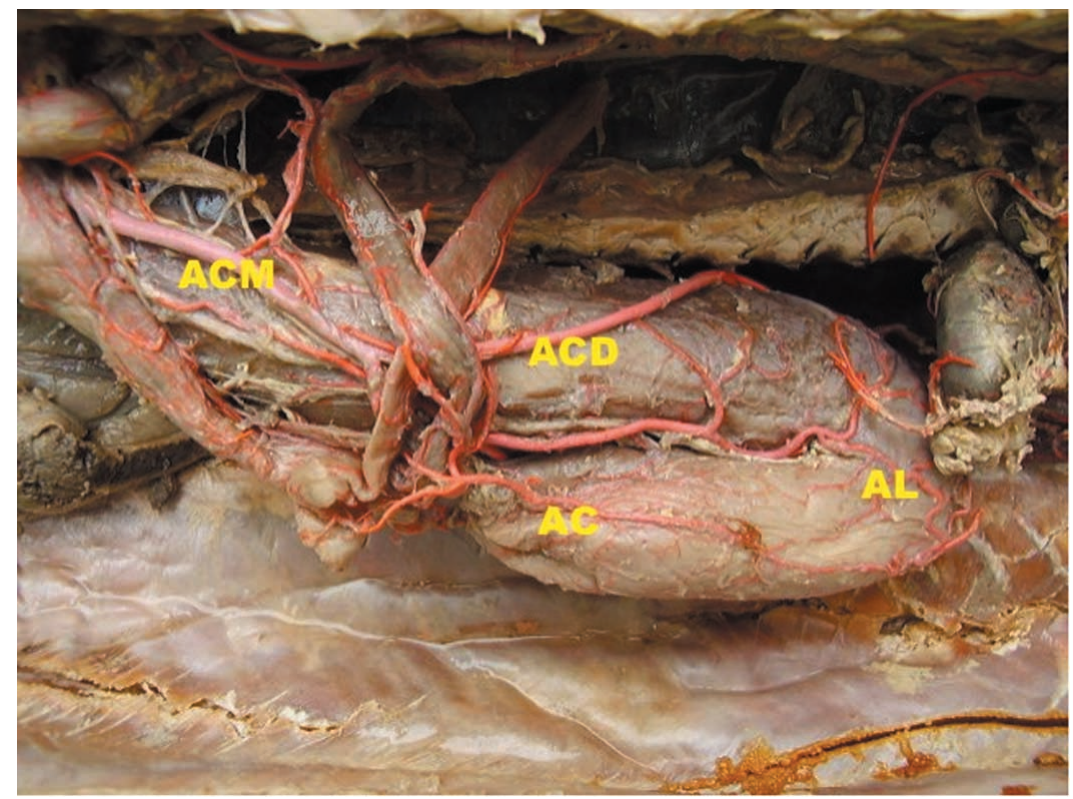

Fig. 2. ACM - celiacomesenteric artery, AC - celiac artery, ACD - dorsal cecal artery, AL - splenic artery. originate pancreatic branches. The ventral cecal artery initially issues a branch to the left wall of the pyloric portion of the stomach and ends by ramifying into the ventral cecum.

The cranial mesenteric artery, which originates medianly, veers to the left, ventrally crossing the cardiac portion of the stomach and, approximately in the median third of the left face of the stomach, issues the splenic artery destined to the spleen. The cranial mesenteric artery continues in the caudal direction in the mesentery, issuing innumerable branches to the proximal and median portions of the intestine and finally supplying the caudal mesenteric artery, which is distributed in the distal portion of the intestine.

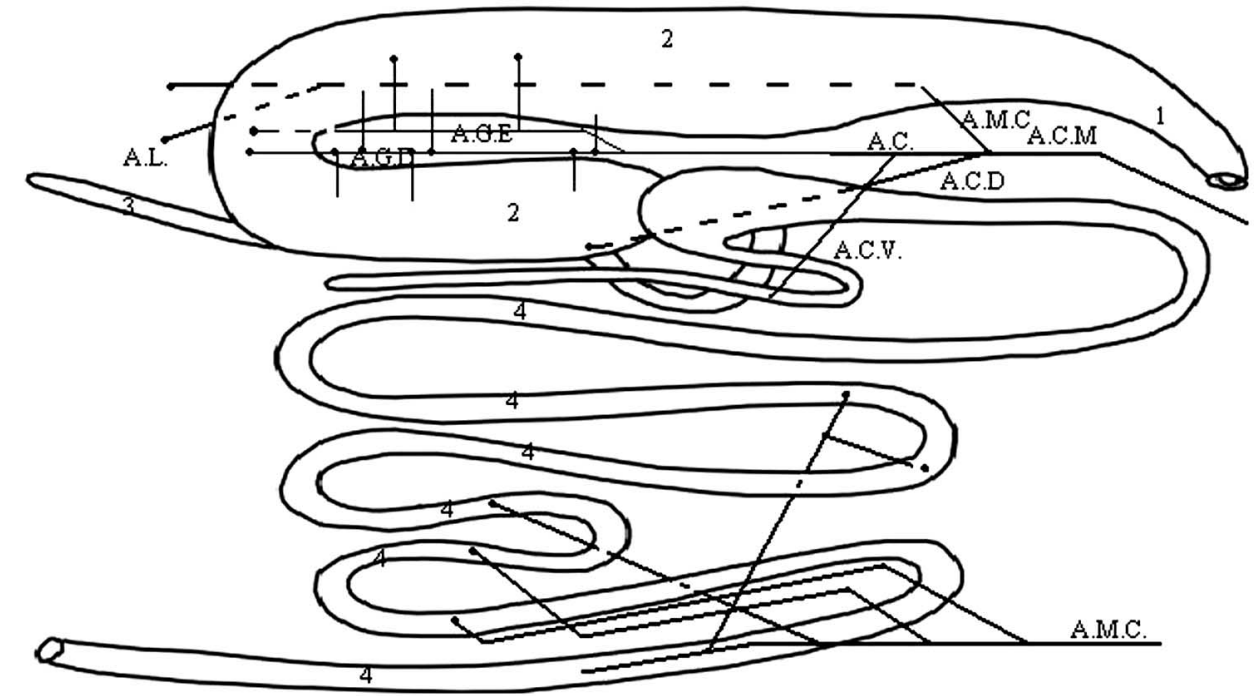

Fig. 3. Digestive tract vascularization: 1) oesophagus, 2) stomach, 3) cecum, 4) intestine, ACM celiacomesenteric artery, AMC - cranial mesenteric artery AC - celiac artery, ACD - dorsal cecal artery, ACV- dorsal cecal artery, AGE - left gastric artery, AGD - right gastric artery, AL - splenic artery.

\section{DISCUSSION}

In their descriptions of the vascularization of the viscera of the celomatic cavity of fishes, Bond, Cailliet et al.; Hildebrand (1995), Romer \& Parsons (1985) and Walker Junior (1965) reported the existence of arteries destined to the various portions of the digestive tube without, however, mentioning the formation of a trunk which, in the pirarucu, is called the celiacomesenteric artery.
According to Danforth (1912), Farrell and Lagler et al. (1977), the celiacomesenteric artery of bony fishes emerges from the dorsal aorta, unlike the pirarucu, in which this artery originates from the $2^{\text {nd }}, 3^{\text {rd }}$ and $4^{\text {th }}$ left efferent branchial arteries.

In his study of perches, Pollack pointed out that the 
SANTOS, A. L. Q.; BRITO, F. M. M.; BOSSO, A. C. S.; VIEIRA, L. G.; SILVA JR., L. M.; KAMINISHI, A. P. S.; SILVA, J. M. M.; PINTO, J. G. S.; MOURA, M. S. \& ROSA, M. A. Anatomical behavior of the celiamesenteric artery of pirarucu Arapaima gigas Cuvier, 1817 (Osteoglossiforme, Arapaimidae). Int. J. Morphol., 25(4):683-687, 2007.

celiacomesenteric artery always originates from the $3^{\text {rd }}$ and $4^{\text {th }}$ right effererent branchial arteries, which is an anatomical peculiarity that most resembles the pirarucu, despite their taxonomic distance.

Likewise, fishes with distant positions in the taxonomic classification present similar anatomical characteristics with respect to the vascular arrangement of the celomatic cavity, as observed in the pirarucu and in other fishes (Danforth; Walker Junior).

Lagler et al. (1977) established a vascular model for bony fishes, without detailing the ramification and distribution of the arteries, unlike that reported by Danforth (1912) and the one found in the present study of piracuru.
As was observed in the pirarucu, Hildebrand, Romer $\&$ Parsons and Walker Junior described the presence, in fishes, of a celiac arteryleading to the stomach, duodenum, liver and pancreas as well as one or more mesenteric arteries to the rest of the intestine.

Although he provided no information about blood vessels, Al-Hussaini (1949a and b) attempted to relate the structural, anatomical and/or histological characteristics of the digestive system of fishes to their feeding habits and behaviors. This information demonstrates the importance of previous anatomical knowledge of the region to be studied.

ACKNOWLEDGEMENT: Tanks Karine Pena Fayad for the spanish translation.

SANTOS, A. L. Q.; BRITO, F. M. M.; BOSSO, A. C. S.; VIEIRA, L. G.; SILVA JR., L. M.; KAMINISHI, A. P. S.; SILVA, J. M. M.; PINTO, J. G. S.; MOURA, M. S. \& ROSA, M. A. Comportamiento anatómicco de la arteria celiacomesentérica en pirarucu Arapaima gigas Cuvier, 1817 (Osteoglossiforme, Arapaimidae). Int. J. Morphol., 25(4):683-687, 2007.

RESUMEN: El pirarucu, pez de la familia Arapaimidae, es una de las especies más importantes y emblemáticas de la ictiofauna amazónica. Para estudiar las características anatómicas de su sistema circulatorio, fueron utilizados 10 ejemplares de Arapaima gigas, con un longitud total media de $74 \mathrm{~cm}$, provenientes de lagos del río Araguaia, São Miguel do Araguaia, Goiás, Brasil. A los peces se les abrió la cavidad celomática donde se identificó y canalizó la arteria aorta dorsal, injectándose una solución coloreada de látex sintético. La fijación del material se realizó con inyecciones de formol al 10\%. La arteria celiacomesentérica es responsable de la irrigación del tubo digestivo y tiene origen en las $2^{\mathrm{a}}, 3^{\mathrm{a}}$ y $4^{\mathrm{a}}$ arterias branquiales eferentes izquierdas. El estómago está irrigado por la arteria celíaca y por una rama gástrica de la arteria cecal ventral. El intestino recibe ramas arteriales procedentes de la arteria celiacomesentérica y de las arterias mesentéricas craneal y caudal; los ciegos dorsal y ventral están irrigados por las arterias cecales dorsal y ventral, respectivamente.

PALABRAS CLAVE: Arapaima gigas; Arterias; Estómago; Intestino; Osteoglosiformes.

\section{REFERENCES}

Al-Hussaini, A. H. On the functional morphology of the alimentary tract of some fishes in relation to differences in their feeding habits. Anatomy and histology. Quarterly J. Microscopical Science, 90:109-39, 1949a.

Al-Hussaini, A. H. On the functional morphology of the alimentary tract of some fishes in relation to differences in their feeding habits. Anatomy and histology. Quarterly J. of Microscopical Science, 90:323-54, 1949b.

Bond, C. E. Biology offishes. 2. ed. Orlando, Sauders College Publishing, 1996.

Cailliet, G. M.; Love, M. S. \& Ebeling, A.W. Fishes: a field and laboratory manual on their structure, identification, and natural history. Belmont, Wadsworth Publishing Company, 1986.

Danforth, C. H. The heart and arteries of Plydon. J. of Morphology, 23:409-54, 1912.
Davison, W.; Axelsson, M.; Nilsson, S. \& Forster, M. E. Cardiovascular control in antartic notothenioid fishes. Comparative Biochemistry and Physiology, 118(A):1001$8,1997$.

Donald, J. A.; Broughtou, B. R. S. \& Bennett, M.B. Vasodilatador mechanisms in the dorsal aorta of the giant sholvenose ray, Rhinobatus typus (Rajiforme; Rhinobatidae). Comparative Biochemistry and Physiology,137(A):21-31, 2004.

Evans, D. H. Vasoactive receptors in abdominal blood vessels of the dogfish shark (Squalus acanthias). Physiological and Biochemical Zoology, 74 (1)120-6, 2001.

Farrell, A. Cardiovascular system. In: Hoar, W.S.; Ranoall, D. J. (Eds). The Physiology of de fishes. New York, Academia, 1993. chap. 8, pp.219-250.

Guimarães, S. F. O Pirarucu (Arapaima gigas): 
SANTOS, A. L. Q.; BRITO, F. M. M.; BOSSO, A. C. S.; VIEIRA, L. G.; SILVA JR., L. M.; KAMINISHI, A. P. S.; SILVA, J. M. M.; PINTO, J. G. S.; MOURA, M. S. \& ROSA, M. A. Anatomical behavior of the celiamesenteric artery of pirarucu Arapaima gigas Cuvier, 1817 (Osteoglossiforme, Arapaimidae). Int. J. Morphol., 25(4):683-687, 2007.

Caracterização de Populações, Biologia e Cultivo. Disponível em http://www.inpa.gov.br/ pesquisaMostra.php?id=57. Acesso em 15 dez. 2005.

Hildebrand, M. (Ed). Análise da Estrutura dos Vertebrados. 3. ed. São Paulo, Atheneu, 1995.

Hill, J.V.; Davison, W. \& Forster, M.E. The effects of fish anaesthetics (MS222, metomidate and AQUI-S) on heart ventricle, the cardiac vagus and branchial vessels from Chinook salmon (Oncorhynchus tshawytscha). Fish Physiology and Biochemistry, 27 (1/2):19-28, 2002.

Lagler, K. F.; Bardach, J. E.; Miller, R. R.; Passimo, D. R. M. Ichthyology.2. ed. New York, John Wiley and sons, 1977.

Lo, W. Y.; Chang, C. F. \& Song, Y. L. Evaluation of dorsal aorta canulation for immunological studies of grouper (Epinephelus malabaricus). Fish \& Shellfish Immunology. 14:289-303, 2003.

Matsushita, L.Y. Estudo da anatomia comparada do sistema cardiovascular de Hoplias malabaricus (Bloch, 1794), Hoplerythrinus unitaeniatus (Spix \& Agassiz, 1829) (Erythrinidae) e Prochilodus lineatus (Valenciennes, 1836) (Prochilodontidae) (Characiformes, Ostariophysi, Pisces). 2001. 82pp. Dissertação (Mestrado em Anatomia Animal)-Instituto de Biociências, São Paulo, 2001.

Pollak, A. The main vessels of the body and the muscle in some Teleost fish. Part I. The Perch (Perca fluviatis). Acta Biologica Cracoviensia, 3:115-38,1960.

Richter, M.; Viana, M. S. S. \& Malabarba, M. C. S. L. Agnatos e Peixes. In: Carvalho, I. S. (Ed). Paleontologia. Rio de Janeiro, Interciência, 2000. chap 28, pp. 497-524.

Romer, A. S. \& Parsons, T. S. Anatomia Comparada dos Vertebrados. 5. ed. São Paulo, Atheneu, 1985.

Silva, N. R.; Santos, A. L. Q.; Ferreira, F. A.; Pinese, J. F. Adaptação, aclimatação e desenvolvimento do Pirarucu (Arapaima gigas) em criação intensiva. Veterinária Notícias, Uberlândia, 1(1):57-61, 1995.

Val, A. L. \& Almeida-Val, V. M. F. Fishes of the Amazon and their environment: physiological and biochemical aspects. Heidelberg, Springer-Verlag Berlim, 1995.
Vogel, W. O. P.; Hughes, G. M. \& Mattheus, U. Non respiratory blood vessels in Latmeria gills filaments. Philosophical Transaction of the Royal Society of London Biological Sciences, London, 353, (1367): 46575. 1998.

Walker Junior, W. F. Vertebrate dissection. $3^{\text {th }}$ ed. W.B. Saunders Company, London, 1965.

Correspondence to:

Dr. André Luiz Quagliatto Santos

Laboratório de Pesquisa em Animais Silvestres

LAPAS, FAMEV/UFU.

Av. Amazonas, $\mathrm{n}^{\circ} 2245$

CEP: $38405-302$

Jardim Umuarama,

Uberlândia-MG

BRASIL

Fone: 55 - 34 3218-2696

Email: quagliatto@famev.ufu.br

Received: 17-05-2007

Accepted: 03-08-2007 
